\title{
Numeracy Culture among Primary School Pupil
}

\author{
Siti Rahaimah Ali \\ Sultan Idris Education University \\ Perak, Malaysia
}

\begin{abstract}
Numeracy culture is a part of mathematics and intertwined with each other. In particular, numeracy is the ability to perform basic mathematical operations and understand simple mathematical ideas and apply knowledge and skills of mathematics in everyday life. Numeracy knowledge is very important to learn from an early stage as numeracy encompasses recognize numbers, basic computation, measurement, geometry, probability and statistics. This article will discuss the culture of numeracy in primary schools. Mental visualisation are used to seeing cultural numeracy among primary school pupil. Through a culture of student mental picture can be seen by their existing knowledge of a particular topic. Culture numeracy in primary schools ensuring excellence at a higher level again. This is because the culture of numeracy in the classroom, students can apply knowledge of numeracy in everyday life. Culture numeracy from an early stage can help students give correct answers by linking basic questions numeracy. Culture numeracy in primary schools is very important for students to understand because every topic related to each other. The word 'culture' is something that is complex and can take a variety of meanings, especially in numeracy. Culture depends on the context numeracy and what is expected of students. Therefore to know what students actually understand about the culture, a lot depends on how teachers identify, collect, and interpret the evidence. When a topic or concept that has been studied, it does not necessarily change when a new or different information found. Being able to obtain new information or knowledge does not entitle a student a full understanding. A student who gains full understanding will be able to express it verbally or simply displaying his skill.
\end{abstract}

\section{Keywords}

Culture numeracy, pupils, primary school, numeracy

\section{INTRODUCTION}

The word "culture" itself is a complex and can bring a lot of meanings especially in numeracy. Culture depends on the numeracy contexts and what is being hoped by the pupils. Numeracy culture is a part of Mathematics and intertwined with each other. The knowledge of numeracy culture has existed since the young age of pupils, that they acknowledged numbers and objects even without understanding wholly (Fosnot, 2007). This is because numeracy in Malaysia has been introduced at the level of primary school when Kurikulum Baru Sekolah Rendah (KBSR) was introduced back then in 1983. Numeracy at the level of primary school includes the basic of counting skill, also understand the easy mathematical ideas. The importance of numeracy is the basic to continuity of learning mathematics to a higher level, also a platform to learn other subjects.

When curriculum was formulated into Kurikulum Bersepadu Sekolah Rendah in 1993, the emphasis on numeracy was continued to help pupils expanding their basic numeracy skill.
In accordance with that, implementation of numeracy needs expert teachers to apply the knowledge of mathematics (concepts and skills) in teaching numeracy to pupils. With that, government's notion to see pupils seizing basic numeracy skills after going through primary school education (KPM, 2010) will be achieved. In 2010, Kementerian Pelajaran Malaysia (KPM) has implanted an early numeracy screening to grade one pupils, and the result came out $46 \%$ of them passed above the numeracy level.

In particular, numeracy is an ability to make basic operation of mathematics and understanding easy mathematical ideas also applying knowledge and mathematical skills in daily life (Kementerian Pelajaran Malaysia, 2010). Numeracy culture as known as numeracy knowledge is important to be learnt from the beginning stage because numeracy consists of various aspects including identifying numbers, basic counting, measurements, geometry, probability, and statistic. In Malaysia, topics in Mathematics in the primary school level includes the aspects that need to be learned by pupils in this stage.

Thus, numeracy culture needs to be applied in pupils from the beginning of learning (KPM, 2001; O'Donoghue, 2002), this is because most of the pupils only knew how to do an algorithm calculation without knowing the reasons behind the operations and can be used in daily life (Brown et al. 2003; Earle, 2003; Bobies, 2005; Clarke, 2004). Numeracy culture in primary school level defines further excellence in a higher level. This is because numeracy culture in class can apply numeracy knowledge in daily life (Westwood, 2008).

According to The Curriculum and Education Standard for School Mathematics (NCTM, 2000) and Department for Education and Skill, UK, (2011), numeracy is an ability of doing a basic calculation, understanding numeral system, ability to solve problem quantitatively and gathered culture data also can be applied in the form of tables, graphs, and diagrams. Some understand numeracy as an ability of reading, writing, calculating and arranging numbers until thousands, also efficient in basic mathematical operations such as addition, substraction, multiplication and division also can be applied in money, time and length measurement operation (Projek Kia 2M, KPM, 2009).

Many researches have been made by national and local researchers to acknowledge numeracy culture in pupils. Some of the researches were carried out involving numeracy (Higgin, 2001, 2002; Berteletti, 2010; Doig, 2003; Zevenbergen, 2004; Coles, 2002; Hogan, 2002), numeracy skills (Ginsburg, 2000), addition and substraction (Matthijsse, 2000), numeral concepts (Higgins 2003; Thomas et al., 2003). In fact, since 1980s researcher group of Rational Number and Proportion Project (Behr, Harel, Post \& Lesh, 1992) has done a research to identify sub-constructnumeracy and the connection between the sub-construct. For example in numeracy, pupils have to expert in knowledge about measurements topic because measurements include length, 
time, temperature, measurement unit, meter, and celcius degree. This skills need to be understood by pupils because these skills can be used and applied in real life.

In the 1990s, NSW Department of Education \& Training, (2001, 2002) and Brown (2000) has made a research towards a group of students to review their understanding knowledge about numeracy and reasons failing in numeracy. In Malaysia, numeracy culture aspect needs to be look upon because ultimate mathematics primary school curriculum goal is to raise balanced pupils from both understanding concept and seizing skills aspect to be applied in real life (KPM, 2002, 2006).

\section{ACHIEVEMENT AND METHOD OF LEARNING IN NUMERACY}

Achievement in numeracy in Malaysia that has been made by Trends in International Mathematics and Science Study (TIMSS), 2011, shows that there is not much increased achievement from 2003 to 2007 especially in geometry, number, algebra and data. The result shows students do not manage to master topics in numeracy. Most of the questions stated by TIMSS tested students in various topics that connected with one another. Numeracy culture from the beginning could help these students to give out correct answers, connecting numeracy culture basic questions. According to Fuson (2003) students could solve addition and substraction questions involving numbers more than one digit. $\mathrm{He}$ also found out that to solve problem in addition involving two digits, some of them counted more than ten using the collecting objects method to every number and recalculating after fusing those objects.

For substraction questions, same method has been used but to substract some of the objects and recalculating it again. Some of the students calculated in multiples 'tenth' then calculated once again in 'ones'. For example, $48+26=74$, students solved by calculating, 48, 58, 68, 69, 70, 71, 72, 73, 74 which was $48+20$ resulting, $68+6=74$. There were students who added the number in bigger multiples and substracted afterwards to get the answer. For the previous example, students solved the questions by $48+30=78$, and then substracted by $4(78-4=74)$.

Furthermore, Geary (2000); Perry (2000); Wright (2000); Thompson (2000); Fuson (1990) have made a research in primary school level to review methods used by students to do addition and substraction operations. The results found out that students used three calculating methods where all of those consisted of using fingers. In the first method, children folded or unfolded their fingers continuously while counting. If the calculation started using fist, fingers were unfolded one by one according to the questions given. The contradiction happened if the calculations was initiated using opened hands, thus calculation was made by folding fingers one after another. Answers were obtained by recalculating folded or unfolded fingers.

Second method used by students in Korea, according to Fuson was by fixing one hand to represent a fine. Students folded and unfolder their fingers continuously to solve the given questions. If children initiated calculation by folding fingers for a fine, they needed to unfolded it again when the fines went above five. The third calculation method that has been used was students calculated second fine continuously. For example $7+4$, they would say it aloud 'seven' and continue folding their fingers while counting 'eight' 'nine' 'ten' and 'eleven'. The result from the research shows that students use counting method using their fingers to solve questions involving addition and substraction. $95 \%$ of the experiment samples gave out correct answer for calculation until ten and $87 \%$ for calculation bigger than ten.

Mental calculation also one of the strategies used to solve numeral problems. Baroody (2003) has made a research on mental calculation on thirty sixth grade students in Mexico. Eighteen of them were chosen to undergo an interview regarding mental calculation. They also were asked to explain how they solved the question given. The question given involved all the four operations. Result shows that only $63 \%$ from the experiment samples get the correct answer. Apart from that, only one hundred out of three hundred and fifteen questions given were solved using other methods rather than normal algorithm. Learnt algorithm has been used by students even in mental calculating. Conclusion that can be made is achievement in mathematics for primary school students depends on the numeracy culture in the beginning especially numeracy concepts (Ball, 2003).

\section{NUMERACY CULTURE}

Numeracy culture in primary school level is very important for students to understand because every topic are connected between each other. Gwen (2007) has made a research, reviewing numeracy strategy for mental calculating used by students in the final of primary school. Numeracy strategy was introduced in 1999, and five years after, 2005, the result showed numeracy culture has fixed students performance mentally. Students could not master these topics without numeracy culture in the first hand and whatever strategies taught depend on the learning beforewards (Murphy, 2004).

Therefore, to really acknowledge what is understood by students, depends on how teachers understand, collect, and translate existed evidences. When a topic or concept has been learnt, not necessarily it would not change when a new or different information found. A man might get a new information or knowledge but does he really understand it? When a certain student understands something, he can address what he knew orally or show his skills. For example, numeracy culture for 'circle', pronouncing the word 'circle' as stimulus response relationship. Student can learn other objects as circle. Next, student can learn how to differ between circle and other objects such as square and triangle. It is important for student to be exposed to circle in various conditions to make sure they know circle in complex objects. When students knew circle, they showed they obtained circle concept culture spontaneously. Students can analyse the concepts in every condition once they mastered in a certain numeracy concept.

According to Kilpatrick et. al. (2001), a student that does not understand concepts and skills of numeracy will come upon trouble in learning Mathematics. Concept culture is a vital in learning Mathematics. Student who could not master the concepts, consider Mathematics is a hard task. Research made by Wallance (2000) has found out that connection culture is the key of success in numeracy. He says, high ability in numeracy depends on the ability of understanding a much lower numeracy, that is in a hierarchy form. This is because every topic is intertwine with one another. Most of the students could not solve the problem as a result of not mastering the concept from the initial or misunderstanding the concept. 
According to Steen (2007), students tend to misunderstand the concept in numeracy. Students who achieve high concept culture level in numeracy are consider getting quality knowledge and it can be nurtured and expanded afterwards. He also states that the concept formation in students' minds is a process that takes time and complexes. Naturally, a concept initially is blurry and soon will be adjourning brightly and clearly after understanding. It depends on student's experience and his maturity level in thinking. Most of the students who came upon problems consist of those who had very little life experience or did not achieve needed maturity level and this brought to various form of perceptions and wrong speculations in the learning and teaching processes.

According to a research carried out by Noraini Idris (2003) about the addition whole numbers scheme on three students from second grade and three students from third grade di one of the primary schools in Kuala Lumpur, has brought her upon that basic numeracy concept such as tenth concept, camutative concept, numeral concept also counting skill, take important role in helping students creating a great scheme on whole number addition. Students were found solving addition because basic numeracy concept has been known by students. Therefore, mathematics education process puts attention on forming basic numeracy to produce mathematical-cultured generations (KPM, 2001a). An individual can have the opportunity to explore knowledge, creating adaptions, modifications and innovations in finishing or handing changes and challenges in the future. This goal is in line with national education philosophy statement (PFK).

Piaget has classified number of object in small group of subtising. Naturally, students from the age of four years old can count. This skill appears depending on their mind ability to form images and numbers culture. Therefore, students count even without understanding but using the memorizing method. For example, there is a digit 6 including images such as on a dice or a card thus students can pronounce the number. Usually, if students are exposed with objects bigger than five, other mental strategies must be used. For example, a group of six objects is divided into two groups of three and when it is reformed, it totals up six. There is a culture that a few (in this case six) can consist of smaller compartment, together with the knowledge that 'three plus three equals six'. This type of mathematical thinking starts from the beginning of the school and must be nurtured because it is a basic for numeracy culture operation and building culture in calculation strategy.

In the primary school level, students learned basic calculating concept to understand the number size and relationship, value and operation. However, students creating this culture in different proportion. Some of the students can count thirteen objects, but they could not foresee that thirteen is actually a group of tenth and three ones. Griffin (2004) has made a research on numeracy culture concept and value places concept. Students involved were found having different culture concept with one another.

According to a research carried out by Amin Salleh, Mahiran Abu and Faridah Abu Hassan (2002) from the Research and Planning Department of Kementerian Pendidikan Malaysia predict that in a certain time, about $10 \%$ of students in primary school have learning problem especially in numeracy culture. Numeracy culture includes every topic in primary school mathematic syllabus, one of the examples, the basic numeracy skill, the geometry is taught formally in primary school starting from first grade to sixth grade. Thus, childrens in Malaysia are considered master in identifying shapes specifically triangle, square and circle when they start learning them in primary school.

Therefore, numeracy culture of identifying number concept in the initial stage for students must be put on attention. Identifying numbers is hard to make sure it is correct, but generally it refers to organized frame work including information concept on numbers and relation between numbers also solving mathematical problem that does not intertwined with traditional algorithm; (Bobis, 2006). The National Council of Teachers (USA, 2009) identifies five components in knowing numbers that are, number meaning, relation between number, number magnitude, numberinvolved operation and quantity. Research carried out by Munirah (2000) resulted that students in Malaysia can do arithmetic calculation very well but they do not sensing the number calculation thoroughly. This skill is fundamental because they donate on general intuition about number and put numeracy basic for further skills.

\section{TEACHERS ROLE IN NUMERACY CULTURE TEACHING}

Primary school education is very vital for the continuity to the next higher educational level, 'teachers are influential agents to achieve educational goals' (Noraini Idris, 1994). Ball (2002) also firmly states that quality of teaching depends on what have been done by the teachers and their attitudes depend on their mathetical knowledge. No doubt that using these connected knowledge, teachers can help students gaining numeracy culture like what has been dreamed by the mathematical educational. Therefore, teachers must apply their knowledge to make a success in teaching numeracy culture especially towards primary school students.

The importance of teachers' knowledge in teaching numeracy culture needs to be documented so that it can be refences (Russell \& Martin, 2001). In the same expand, knowledge and teachers' teaching habit are fundamental components to make sure students understand numeracy. Rangka Tindakan Pendidikan Kebangsaan Malaysia (2006-2010) identified that increasing teachers professionality is one of vital components to the successful education in Malaysia. Researches showed that teachers have a big role in students' achievements (Hill et al, 2005). Since two decades ago, efforts to give accurate explanation on teachers' knowledge have been given same attention starting from every kind of needed information to teach basic numeracy. Doing a hard challenge shows that teachers' knowledge on numeracy must be used in every method in teaching numeracy so that students understand basic numeracy concept (Bass, 2005; Heaton, 2000; Yackel, 2002).

Research has been made by Wright (2002), aiming to creating teaching criteria and habit, supporting teachers also forming teachers' numeracy culture. Collected data through primary school teachers interviews, classroom reviews, and other artifacts examinations such as teachers' teaching planning, teaching items, resources used in teaching. Observations is recorded for analysis. However, the result of initial analysis data shows that appearance of specific teaching aspects such as criteria of a good teacher and involvement of students is really working. Another teaching aspects such as teachers' pedadogy knowledge in numeracy, sometimes teachers might come upon problems if some of the students fail in numeracy. So, teachers need to continue with another topic even if there is still some students that quite not understand basic 
numeracy. Teachers role is very fundamental especially in teaching and learning processes generally, numeracy culture must be nurtured in the beginning specifically (KPM 2010).

In United States, National Council of Teacher of Mathematics (NCTM) has published deviation as "The Curriculum and Evaluation Standards for School Mathematics" (NCTM,1989) and "The Principles and Standards for School Mathematics" (NCTM, 2000) as an effort to increase teaching and learning quality in Mathematics especially in numeracy culture knowledge. One of them is learning the topic of fraction is an extension of learning whole number and every education ought to help creating the fraction culture concept (NCTM, 2000) so that numeracy culture among students will be achieved.

Numeracy culture knowledge is very important to be achieved by children to get them understanding the process, concept and basic skill of numeracy. Fun and joyful teaching process will attract students' attention in joining activities in the process of learning, plus creating the convincing culture. This process must exist in every individual of students because numeracy knowledge culture will be applied in their real life (Steen, 2000). When students understand numeracy directly, achievements in Mathematics can be increased.

Therefore, the importance of teachers' knowledge in teaching has to be documented (Gess-Newsome, 2000; Graeber, 2000; Munby, Martin, 2001) to be references in both teaching and learning processes. In the same expansion, knowledge and habit of teaching numeracy are important components to ensure students can create numeracy culture. Rangka Tindakan Pendidikan Kebangsaan Malaysia (2006-2010) is identified that increasing teachers profession is one of vital components to achieve education success in Malaysia. Studies show that knowledgeable teachers especially in numeracy carry big influences to their students' achievement (Hill, Rowan (Plaveholder1); Ball, 2005). Since two decades ago, efforts to give out accurate explanation in teachers' knowledge are given the same attention from the needed type of knowledge to teach, value basic knowledge for teaching or professional knowledge (Carlson, 2000) and practical knowledge (Clandinin, 2005). Study made on teachers who teach numeracy has been made in countries such as United Kingdom, Australia, United States and Malaysia (Askew et. al. 1997, Reys, 2006, Munirah, 2003).

In line of that, the goal in lower mathematics education in Malaysia is to "create culture about basic concept and skill in calculation to ensure students apply in their daily life meaningfully" (Kementerian Pelajaran Malaysia, 2003). "Knowledge application skill especially culture about numeracy in daily life meaningfully" curriculum that has been formulated by other countries including Singapore (Curriculum Development and Planning, 2001) and United States (NCTM, 2000). Generating problems skill is very fundamental for teachers as a method that gives them the courage in teaching. Sending out questions in education is a norm (Noraini Idris, 2009), the more the questions generated by teachers, the more the culture can be created because by question and answer session can help students to think and trigger quality ideas (Noraini Idris, 2009).

Study in National Numeracy Strategy (2010) shows teachers role in teaching numeracy where they explore trust, knowledge and culture since teachers' training. The result gives out that effective teachers in teaching numeracy help students and apply knowledge about numbers, relation between numbers and operation of numbers involving integration from culture, technic, strategy and applying skills in various contexts to build vast connection network between the mathematical ideas and students.

According to Muir (2008) study has made by creating observation tables to evaluate effective teaching in numeracy. He finds that the determination of teachers in a good teaching by giving out suitable examples, using concrete items, fast calculation and using open questions as important components in numeracy teaching. Study shows that teachers with high numeracy knowledge give big influences towards students achievements (Hill, 2005).

A certain teacher play an important role in delivering information effectively to students to ensure students can understand and store the information for a really long time. This is to ensure it can be used if students face problems that need solution of basic numeracy. Therefore, effective culturelearning concept can increase memorizing skill of a student.

\section{NUMERACY KNOWLEDGE THEORY}

Numeracy knowledge uses Constructivism Radical Theory (TKR). This theory predicts students always building information according to experience experienced and it does not have a right or wrong. According to Von Glasersfeld (2007), knowledge happens through assimilation and accommodation to create viable scheme. Therefore, to understand ways people understand numeracy level, analysis regarding behavior and speech needs to be interpreted. This interpret is a misfits, but not the same as numeracy concept on references books. This is because TKR predicts people do not have to ability to know the truth, reality surrounding them.

Therefore, Von Glasersfeld (2001) states this theory denies the existence of absolute truth, but human's ability limits them to know the truth. This means interpretation towards one's conception is not statistical like a piece of paper that can be found in a file, but relatively dynamical like a complete program or producing activities ready to be used.

With that, numeracy knowledge for primary school students applied according to some assumptions such as, students must create numeracy knowledge culture actively through learning process experienced. Knowledge built in students adaptively through ready experience to create viatable knowledge and does not have right or wrong; students' numeracy knowledge can be interpreted from their behaviors while doing activities in interview sessions, and interaction between researcher and sample is an act of modeling students knowledge. Numeracy knowledge can be interpretered from observations on their behavior repeatedly in different task contexts.

\section{THE IMPORTANCE OF NUMERACY CULTURE}

The importance of numeracy culture from the aspect of expanding knowledge and contribution towards theory also teachers' training. From the aspect of expanding knowledge, deep investigation-like study regarding the cognitive of primary school students in mathematics education is still limited, especially in numeracy knowledge culture. As we can see, numeracy is important in Mathematics, therefore it can contribute to increased knowledge specifically in numeracy culture and numeracy knowledge levels generally. This knowledge can be used to help teachers modeling suitable activities in the processes of both learning and teaching from 
students' aspect, not from curriculum's aspect per se.

For example, to help new students initiating school create concept culture of numeracy, a lot of items can be used such as conretes, symbols shown by students and their surrounding so that learning situation can support their creation of culture. In other words, to ensure students understand what is needed in learning, teachers must be alert on students' necessities in curriculum contexts that have been formulated by Kementerian Pelajaran Malaysia (KPM). This is important so that what is planned by teachers is in line with numeracy knowledge own by students and curriculum vision.

The result also shows it is import to expose teachers on importance of modeling suitable approach according to students' individual because that culture is a basic of diagnosing students culture individually in certain learning situation. Therefore, the result obtained can be used as a guide to make recovery activities to those students in need.

Primary school teachers centre of training, Institut Pendidikan Guru Malaysia (IPGM) plays a big and vital role to create efficient training teachers in pedadogy knowledge resourcefocused, technology, curriculum, methods. Mathematics is a concept that could not be transported by teachers to students, teaching approach that is too depending on language speaking has limit. Therefore, it can be a guide for IPGM to give attention to understanding creation element specifically, while behavior theory and information processing in mathematics curriculum. This is important so that mathematic education vision is in line with other growing countries that has a better mathematical position in a national level.

\section{REFERENCES}

[1] Amin Salleh, M. A. (2001). Laporan Pembelajaran. Kuala Lumpur: Bahagian Perancangan dan Penyelidikan, Kementerian Pelajaran Malaysia.

[2] Askew, M. B. (1997). Effective teachers of numeracy. London School of Educational .

[3] Ball, D. L. (1993). Halves pieces and twoths: constructing and using representational contexts in teaching fraction. In E. F. T.P Carpenter, Rational numbers: an intergration of research (pp. 157-195). Hillsdale: Lawrence Erlbaum.

[4] Ball, D. (2002). Mathematical proficiency for all students: Toward a strategic research and development program in mathematics education. RAND Education/Science and Teknology Policy Institute.

[5] Ball, D. (2003). What mathematical knowledge is necessary for teaching mathematics. USA: US Department of Education.

[6] Bass, H. (2005). Mathematics, Mathematicians and Mathematics Education. Bulletin of the American Mathematics Sociaty 42 (14) , 417-430.

[7] Behr, M. H. (1992). Rational number, ratio and proportion. Dlm D.A Grouws (Ed). Handbook of research on mathematics teaching and learning: A project of the National Council of Teachers of Mathmematics . 209-333.

[8] Bobies, J. C. (2005). Supporting teachers in the development of young children's mathematical thinking:Three Large scale cases . Mathematics Education Research Journal 16(3) , 27-57.
[9] Bogdan, R. \&. (2003). Qualitative research for education: An introduction to theories and methods (4 ed). Boston: Allyn and Bacon.

[10] Brown, M. A. (2003). The key role of educational research in the development and evaluation of the National Numeracy Strategy. British Educational Research Journal 29(5), 663-680.

[11] Carol Murphy (2004). How the Children come to use a taught mental calculation strategy? Educational Studies in Mathematics 56(1) , 3-18.

[12] Carlson, R. (1990). Ssessing teachers' pedagogical content knowledge: Item development issues. Journal of Personal Evaluation in Education,4 , 157-173.

[13] Clandinim, D. J. (2005). Personal Practices knowledge: A study of teachers'classroom images. Curriculum Inquiry 15 (4), 362-385.

[14] Clarke, D (2004). Mathematics teaching in Grades K-2: Painting a picture of challenging, supportive and effective classrooms. In R.N Rubenstien \& G.W Bright (Eds). Perspectives on the teaching of mathematics (66th Yearbook of the National Council of Teachers of Mathematics. Reston,VA:NCTM

[15] Clarke, D (2006) Proceedings of the 24th Annual Confeernce ot the Mathematics Education Research group of Australasia, Vol 1). Understanding assessing and developing young children's mathematical thinking: Research as powerful tool for profesional growth. In J. Bobis, B Perry \& M. Mitchelmore (Eds). 9-26.

[16] Coles, D. \&. (2002). Numeracy and mathematics across the primary curriculum. London: Fulton.

[17] Doig, B. M. (2003, january 31). A good start to numeracy: Effective numeracy strategies from research and practice in early chilhood. Retrieved Februari 17, 2012 , from http://www.dest.gov.au/archive/schools/publications/200 3/goodstart: http://www.dest.gov.au/archive/publications/good start.pdf

[18] Fosnot, C. \&. (2007). Mini lessons for extending addition and subtractions a yearlong resource, contexts for learning, $k-3$. Portsmounth: Nh:Heinemann.

[19] Fuson, K. \&. (1990). Using a base-ten bloks learning/teaching approach for first and second-grade place value and multi-digit addition and subtraction . Journal for research in mathematics education 21,180 206.

[20] Fuson, K. (2003). Developing mathematical power in whole number operation. In J. kilpatrick w.g. Martin and D. Schiffer. A research companion to principles and standards for school mathematics, 68-98.

[21] Geary, D. (2000). The development of numerical and arithmetical cognitif: A longitudinal study of process and concept deficits in children with learning disability. Journal of Experimental Child Psychology, 77 , 236-263.

[22] Munirah Ghazali, (2000). Kajian Kepekaan nombor murid tahun lima. tesis Phd. tidak diterbitkan. Johor: Universiti Teknologi Malaysia.

[23] Ginsburg, L. (2000). Instructional straregies for adult 
numeracy education. Adult numeracy development:Theory, research. practise , 89-114.

[24] Van Glaserfeld, V. (1987b). Preliminaries to any theory of representation. Dlm C. Janvier (ed), Problems of representation in the teaching and learningof mathematics . 215-225.

[25] Van Glaserfeld (2007). Radical Constructic. London: The falmer.

[26] Van Glaserfeld (2006). You Have to be two to start: Rational Thoughts About Love. Contructivist Foundations 2, 1-5.

[27] Van Glasersfeid (1995). Radical Contructivisim: A Way of knowing and leraning. Hog Kong: The Falmer.

[28] Van Glasersfeld (2005). Thirty Years Radical Contructivism. Constructivist Foundations 1 (1) , 9-12.

[29] Van Glasesrfeld (2001). The radical constructivisme view of science, foundation of science 6. 31-43.

[30] Graeber. (1999). Forms of knowing mathematics: what preservice teachers should learn . educational studies in mathematics, 38 (1-3), 189-208.

[31] $\mathrm{H} \mathrm{Wu}$ (2005). Mathematic, mathematician and mathematics education. Bulletin (New Series) of the American Mathematical Society 424, 417-430.

[32] Russell, \& Martin (2001). Teacher's knowledge and how it develops. In V. richardson (ed). Handbook of research on teaching , 433-436.

[33] Heather C Hill \& Brian Rowan (2005). Effects of teachers mathematical knowledge for teaching on student achievement. American educational Research Journal 42 (2), 371-406.

[34] Heaton, R. (2000). Teaching Mathematics to the new standards: relearning. New York: College Press.

[35] Higgin, J. (2001). An evaluation of the advanced numeracy project. New Zealand: Wllington, Ministry of Education.

[36] Higgin, J. (2002). An evaluation of the advanced Numeracy Project. New Zealand: Wwllington, Ministry of Education.

[37] Hill, H. Rowan (2005). Effects of Teachers' Mathematical Knowledge for Teaching on Student Achievement. America Educational Research Journal42(2) , 371-406.

[38] Hogan, J. (2000). Numeracy across the curiculum? Autralian Mathematics Teachers Association Journal 56(3) , 17-20.

[39] Noraini Idris (2000). Linguistik aspects of mathematical education: How precise do teachers need to be? In Cultural and Language Aspects of Science,Mathematics and TechnicalEducation. Universiti Brunai Darulsalam.

[40] Noraini Idris (2004). Mathematics learning in English as a second language. Diges Pendidik, 4(1), 64-72.

[41] Noraini Idris(1994). Pengajaran dan pembelajaran matematik untuk sekolah rendah. Kuala Lumpur: Dewan Bahasa dan Pustaka.

[42] Noraini Idris (2009). Penyelesaian masalah daya penggerak dalam pengajaran dan pembelajaran Persidangan Kebangsaan Pendidikan Matematik. Sungai Petani: Institut Pendidikan Guru Malaysia.

[43] Kilpatrick, J. S. (2001). All adding it up: Helping children learnmathematics. Whingston Dc: Nasional Academic Press.

[44] Margaret Brown (2000). What kinds of teaching and what other factors accelerate promary pupil's progress in acquiring numeracy? ACER Research.

[45] Heaton R.M (2000). Teaching Mathematics to the new standard: Re learning to dance. New York: Teaching College Press.

[46] Kementerian Pelajaran Malaysia (2010). Bengkel Kajian Semula Pelan Induk Pembangunan Pendidikan . Teks Ucapan .

[47] Kementerian Pelajaran Malaysia (2009). Huraian Sukatan Pelajaran Matematik Tahun 4. Kuala Lumpur: Pusat Perkembangan Kurikulum.

[48] Kementerian Pelajaran Malaysia Malaysia, K. P. (2003). Kurikulum Bersepadu Sekolah Rendah: Huraian Sukatan Pelajaran Matematik Tahun 4. Kuala Lumpur: Pusat Perkembangan Kurikulum.

[49] Lembaga Peperiksaan Malaysia (2011). Analisa prestasi dan gred purata matematik. Kuala Lumpur: Lembaga Peperikasaan Malaysia.

[50] Matthijsse, W. (2000). Adult numeracy at the elementary level: Addition and subtraction up to 100. In G. Iddo, Adult Numeracy Development: Theory, research, practise (pp. 133-155). UK.

[51] Muir, T. (2008). Describing effective teachig of numeracy links between principles of practice and teachers actions. 11th International Conference on Mathematics Education (ICMG-11) for study group2 New development and trends in mathematics education of primary level. Monterry, Mexico.

[52] Munirah, G. (2000). Kajian Kepekaan Nombor Murid Tahun LIma. Johor: UTM.

[53] Munirah, G (2003). Development of a framework to assess primary students number sense in Malaysia: Counting. SEMT, International Senior For Elementary Mathematics. Repbuplic Czes: Charles University.

[54] NCTM. (2000). Principles and standard for school mathematics. USA: Reston, Va Author.

[55] O'Donoghue, J. (2002). Numeracy and Mathematics. Math. Soc. Bulletin 48 , 47-55.

[56] Perry, M. (2000). Explanations of mathematicsal concepts in Japanese, Chinese, and U>S first and fifthgrade classrooms. Cognition and Instruction, 18 , 181207.

[57] Reys, R. (2007). Helping children learn mathematics (9ed). New York: John Wiley \& Sons.

[58] Reys, R. L. (2006). Helping children lear mathematics (6 ed). . New York: John Wiley \& Sons.

[59] Department of skill (2011). Literacy And Numeracy. Dublin: Department of Education and Skill. 
[60] Steen, L. A. (1999). Numeracy: The New Literacy for a Data-Drenchea Sociaty. Educational Leadership , Volume 57, number 2.

[61] Steen, L. (2007). Every teacher is a teacher of mathematics. Principlsl Leadership, 7,5 , 16-20.

[62] Steffe L.P \& Thompsom, P. (2000). Teaching experiment methodology: underlying principles and essencial elements in R. Lesh \& A.E Kelly (Eds). Research design in mathematics and science education, 267-307.

[63] Strategy Numerasi Kebangsaan. (2011). Primary framework for literacy and mathematics. Department of eductional and skill.

[64] Thomas, G. a. (2008). What do the 2002 school entrants know now? In finding from the numeracy development project 2007. Wellington: Learning Media.

[65] Thompson, I. (2000). Teaching Place Value in the UK: Time for reappraisal? Educational Review. 52(3) , 291298.

[66] TIMSS. (2011). Assessment Frameworks. TIMSS.

[67] Curriculum Development and Planning (2001). Count Me in Too: Profesional development package. Sydney: NSW Department of education \& Training Curriculum
Directorate.

[68] Von Glasersfeld \& Larochelle, M (2007). Key works in radical constructivism. New York: Sense Publishers.

[69] Wallance.D. (2000). The many needs to numeracy. In M.J Burk \& F.R curcio (Eds) learning mathematics for a new centry. Reston.

[70] Westwood, P. (2008). What teachers need to know about numeracy. Australia: ACER press.

[71] Wikipedia. (2011, Disember 6). http://en.wikipedia.org/wiki/numeracy. Retrieved $\begin{array}{llll}\text { Disember 6, 2011, from } & \end{array}$ ht://en.wikipedia.org/wiki/numeracy

[72] Wright, B. M. (2002). Teaching number advancing children's skills and strategies. London: Paul Chapman.

[73] Wright, R. M. (2000). Early numeracy: Assessment for teaching and intervention. London: Chapman.

[74] Yackel, E. (2002). The Teacher's role in collective argumentation. Journal of mathematics Behevior, 423440.

[75] Zevenbergen, R. W. (2004). Teaching mathematics in primary school. Crows nest- allen \& Unwin. 